\title{
Tree mortality and regeneration of Euphrates poplar riparian forests along the Tarim River, Northwest China
}

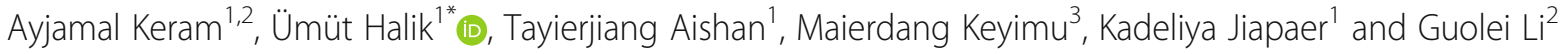

\begin{abstract}
Background: Tree mortality and regeneration (seedling and sapling recruitment) are essential components of forest dynamics in arid regions, especially where subjected to serious eco-hydrological problems. In recent decades, the mortality of the Euphrates poplar (Populus euphratica) along the Tarim River in Northwest China has increased. However, few studies have quantified the causes of mortality and regeneration in this azonal riparian forest type.

Methods: The present study describes the annual hydrological response of tree mortality and regeneration in forest gaps. A total of 60 canopy gaps were investigated in six replicate grid plots $(50 \mathrm{~m} \times 50 \mathrm{~m})$ and the annual runoff and water consumption data during the period of 1955-2016 were collected from hydrological stations in the middle reaches of the Tarim River. We compared the regeneration density of seedlings and saplings within the canopy gap areas (CGAs), undercanopy areas (UCAs), and uncovered riverbank areas (RBAs) through detailed field investigation.
\end{abstract}

Results: Our study found that the mortality of young and middle-aged gap makers has increased remarkably over recent decades, particularly since the year 1996. The main results indicated that regional water scarcity was the primary limiting factor for long-term changes in tree mortality, as shown by a significant correlation between the diameter at breast height (DBH) of dead trees and the annual surface water. The average density (or regeneration rate) of seedlings and saplings was highest in the RBAs, intermediate in the CGAs, and lowest in the UCAs. Compared with the UCAs, the CGAs promote tree regeneration to some extent by providing favorable conditions for the survival and growth of seedlings and saplings, which would otherwise be suppressed in the understory. Furthermore, although the density of seedlings and saplings in the CGAs was not as high as in the RBAs, the survival rate was higher in the CGAs than in the RBAs.

Conclusion: Forest canopy gaps in floodplain areas can play a decisive role in the long-term germination and regeneration of plant species. However, as a typical phreatophyte in this hyper-arid region, the ecosystem structure, functions and services of this fragile $P$. euphratica floodplain forests are threatened by a continuous decrease of water resources, due to excessive water use for agricultural irrigation, which has resulted in a severe reduction of intact poplar forests. Furthermore, the survival of seedlings and saplings is influenced by light availability and soil water at the regional scale. Our findings suggest that policymakers may need to reconsider the restoration and regeneration measures implemented in riparian P. euphratica forests to improve flood water efficiency and create canopy gaps. Our results provide with valuable reference information for the conservation and sustainable development of floodplain forest ecosystems.

Keywords: Tree mortality, Regeneration strategy, Seedling and sapling recruitment, Gap makers, Riparian forest, Tarim River

\footnotetext{
* Correspondence: halik@xju.edu.cn

${ }^{1}$ College of Resources and Environmental Science, Key Laboratory for Oasis Ecology of Ministry of Education, Xinjiang University, Ürümqi 830046, China Full list of author information is available at the end of the article
}

\section{Springer Open}

(๑) The Author(s). 2021 Open Access This article is licensed under a Creative Commons Attribution 4.0 International License, which permits use, sharing, adaptation, distribution and reproduction in any medium or format, as long as you give appropriate credit to the original author(s) and the source, provide a link to the Creative Commons licence, and indicate if changes were made. The images or other third party material in this article are included in the article's Creative Commons licence, unless indicated otherwise in a credit line to the material. If material is not included in the article's Creative Commons licence and your intended use is not permitted by statutory regulation or exceeds the permitted use, you will need to obtain permission directly from the copyright holder. To view a copy of this licence, visit http://creativecommons.org/licenses/by/4.0/. 


\section{Highlights}

- Effect of hydrological alterations on tree mortality of Populus euphratica riparian forest was quantified.

- The contribution of different habitats (canopy gap area, undercanopy area and riverbank area) on plant regenerations was evaluated.

- Recommendations for regeneration and succession of riparian forests at the Tarim River were put forward.

\section{Introduction}

Riparian forests provide fundamental ecosystem services in arid regions, including maintenance of ecological stability and prevention of natural disasters such as sandstorms, heatwaves, and desertification (Song et al. 2000; Chen et al. 2013; Betz et al. 2015; Mamat et al. 2018; Halik et al. 2019). The existence of trees, bushes, and grass vegetation on the banks of the Tarim River, which constitute the natural barriers of river oases, is absolutely dependent on the river (Zeng et al. 2002, 2006; Halik et al. 2006; Aishan et al. 2018). In recent decades, floodplain vegetation has been threatened by increased water scarcity, and large areas of riparian forests including seedlings and saplings, have withered (Gries et al. 2003; Foetzki 2004; Aishan 2016; Zeng et al. 2020). With China's rapid economic development and the implementation of the "Ecological Civilization" and "One Belt One Road" initiatives, the ecological restoration of the floodplain ecosystem along the Tarim River has been designated as a high priority by the Chinese government (Halik et al. 2006, 2019). Conservation of the remaining riparian forests and recovery of the degraded parts of the ecosystem are crucial for further sustainable development of the region (Rumbaur et al. 2015; Deng 2016; China Green Foundation 2018), particularly, transport infrastructure, including railways, highways, and oil and gas pipelines in the Tarim Basin are in need to be protected (Deng 2009, 2016; Aishan 2016; Halik et al. 2019). Thus, it is necessary to preserve the functions and services of these forests through adaptive management.

The riparian forest (also known as Tugai forests) at the Tarim River constitute a natural green belt at the northern edge of the Taklimakan Desert. The Euphrates poplar (Populus euphratica Oliv.) is a dominant tree species in the floodplain ecosystems. As a "Green Corridor", $P$. euphratica forests have become increasingly important for preventing the unification of two neighboring sandy deserts, the Taklimakan and the Kuruktagh (Xu et al. 2006; Betz et al. 2015). These forests have important ecological functions in addition to socio-economic and touristic value, such as protection of biodiversity, regulation of the climate and hydrologic conditions in oases, fertilization of soils, and maintenance of regional ecosystem balance (Wang et al. 1995; Huang 2002; Huang and Pang 2011; Mamat et al. 2019). Nevertheless, the Tarim floodplain ecosystem, especially the riparian vegetation, has been seriously degraded, as the water conveyance in the main channel has rapidly decreased and many tributaries of the watershed have been disconnected from the main river (Zhao et al. 2011; Chen et al. 2013).

Many studies have demonstrated that water shortages in the Tarim are mainly caused by climate change coupled with intensive anthropogenic activities, i.e., tree felling, overgrazing, excessive land reclamation and disorderly expansion of cotton monoculture. Therefore, restoring degraded floodplain ecosystems has become a major focus of applied forest research (Deng 2009; Rumbaur et al. 2015; Thomas et al. 2017; Thomas and Lang 2020). Among all processes of natural forest dynamics, the formation of forest canopy gaps was considered a vital regeneration strategy for maintaining floodplain forest structures (Han et al. 2011; Keram et al. 2019). Gap disturbance is the main driving force of forest dynamics as it creates environmental heterogeneity (Zhu et al. 2003, 2007; Albanesi et al. 2005; Bottero et al. 2011). Forest gaps thus create important habitat for the regeneration of plant species, which may otherwise be suppressed by the undercanopy (Han et al. 2011; Sharma et al. 2018). They also play a vital role in forest regeneration and succession, especially in the establishment and development of plant species that differ in ecological recruitment (Runkle 1998; Mountford 2006; Rentch et al. 2010; Han et al. 2013; Zhu et al. 2014; Jankovska et al. 2015). Nagel et al. (2010) reported a high presence of advanced regeneration in a gap regeneration study of a (mixed) beech virgin forests. Besides, it also has been reported that canopy gaps close when the height of regenerations reached $20 \mathrm{~m}$, consistent with the definition used by Nagel and Svoboda (2008). Zhu et al. (2021) found that with the decreased of gap size, pioneer species became the sub-canopy layer, and with the aging of gap, the light conditions changed over time, which was conductive to the recruitment of shade-tolerant species; Keram et al. (2019) also revealed that hydrological conditions (groundwater, runoff and water consumption) are the main driving force of the gap-scale disturbance of desert riparian forests along the Tarim River. In floodplain forests, canopy gaps may not be filled with regenerations within a short period because of high tree mortality. This leads to the continual expansion of canopy gaps (Keram et al. 2019). The majority of earlier studies have focused on the mortality of gap makers and the diversity of regeneration species in other various climatic zones, such as tropical, subtropical, north temperate, and cold temperate regions (Runkle and Yetter 1987; Yamamoto 2000; Dorotä and Thomast 2008; 
Petritan et al. 2013; Popa et al. 2017; Zhu et al. 2018; Kitao et al. 2018). However, systematic research on tree mortality and plant regeneration of desert riparian forests under various hydrological scenarios are relatively lacking. Therefore, it is necessary to scientifically understand the response of $P$. euphratica mortality rate to hydrological dynamics at regional scales, and seedling and sapling regeneration in the Tarim River Basin.

Forest canopy gaps may provide opportunities for species regeneration and have therefore been widely exploited in forest recovery programs (Coates and Philip 1997; Schliemann and Bockheim 2011; Kern et al. 2013, 2017; Nagel et al. 2016; Lu et al. 2018). Thus, it is necessary to conduct studies to better understand the mortality of gap makers under long-term hydrological processes and seedling and sapling establishment in different habitats, such as canopy gap areas (CGAs), undercanopy areas (UCAs), and riverbank areas (RBAs) of floodplain, as well as to clarify the contribution of canopy gaps to plant regeneration in riparian forests. Such information may provide insights into the efficiency of gap usage and seedling planting in forest restoration activities along the Tarim River. In the present study, we used comprehensive field investigation data to describe tree mortality as well as to compare the density of seedlings and saplings between the CGAs, UCAs, and RBAs to evaluate whether the CGAs are important for the regeneration of $P$. euphratica riparian forests along the Tarim River. In this work we made three hypotheses:

\section{(H1)}

Based on the observation that canopy gap disturbances have frequently emerged in the desert riparian forests and its composition and structure were drastically different from other forest types (Han et al. 2011; Keram et al. 2019). We hypothesized that characteristics of tree mortality (number, DBH) strongly responded to hydrological dynamics (such as stream flow) at local and regional scales in the Tarim River Basin, resulting in the emergence of special forest gap structures.

\section{(H2)}

Conclusions on the size development of canopy gaps, once formed they would continuously expand (Keram et al. 2019). The important process of gap dynamics, i.e. plant regeneration, in floodplain forests has not been quantified yet. To test the general hypothesis, that canopy gaps promote plant regeneration in riparian forests, we formulated the hypothesis that canopy gaps drive tree regeneration to some degree, due to canopy gap provides more adequate light conditions than the UCAs.
(H3)

In floodplain forests, due to the degradation of plant habitat, canopy gaps may not be filled up with other regenerations in a relatively short period. By comparison of the species diversity between gap makers and gap fillers in canopy gaps, we hypothesized that canopy gaps may not be filled up with other regenerations within a short time, (i) which may be due to the degraded habitat of plant growth, (ii) prolonged and unexpected flooding disturbance resulted in the degradation of $P$. euphratica trees, and (iii) its mortality did not cause significant changes in tree distribution but caused changes at tree level.

We intend to verification of these hypotheses by compiling data from six permanent monitoring plots located at undisturbed natural forest sites along the middle reaches of the Tarim River. We believe that addressing these hypotheses will contribute to improve the understanding of the current state of the Tarim riparian ecosystem, where $P$. euphratica is now in urgent need of protection. Additionally, it will provide an ecological framework for the design and implementation of closeto-nature restoration techniques to extend $P$. euphratica forests.

\section{Methods}

\section{Study site}

Field work was conducted in Yingbazha village $\left(41.22^{\circ} \mathrm{N}\right.$, $84.31^{\circ} \mathrm{E}, \mathrm{ASL} 1000 \mathrm{~m}$ ) in Tarim Huyanglin Nature Reserve (THNR) along the middle reaches of the Tarim River (Fig. 1), which was established in 1984 and upgraded to a National Nature Reserve in 2006. The region is an extremely arid warm temperate zone, with an annual mean precipitation of $75 \mathrm{~mm}$ and an annual mean temperature of $11.05^{\circ} \mathrm{C}$ (Keyimu et al. 2018). The annual potential evapotranspiration ranges from 2500 to $3500 \mathrm{~mm}$ (Rouzi et al. 2018). According to the USDA (United States Department of Agriculture) soil classification system, the soil of the Tarim River is a member of the Aridisol order, and the soil is silty loam $(\mathrm{Hu}$ et al. 2009; Yu et al. 2009). The local groundwater system is recharged from the surface water through bank infiltration (Huang et al. 2010). The forest structure and composition in the study area is relatively simple, and the local flora is mainly composed of $P$. euphratica, Tamarix ramosissima and Phragmites australis (Table 1). However, a few rare plant species are also present, including Populus pruinosa, Tamarix hispida, Tamarix leptostachys, Glycyrrhiza glabra, Inula salsoloides, Karelinia caspica, Lycium ruthenicum, Alhagi sparsifolia, Apocynum venetum, Halimodendron halodendron, Poacynum hendersonii, Cirsium segetum, Cynanchum auriculatum, Aeluropus pungens, Taraxacum mongolicum, Salsola collina, Calamagrostis pseudophragmites, Myricaria platyphylla, Halogeton glomeratus, and 


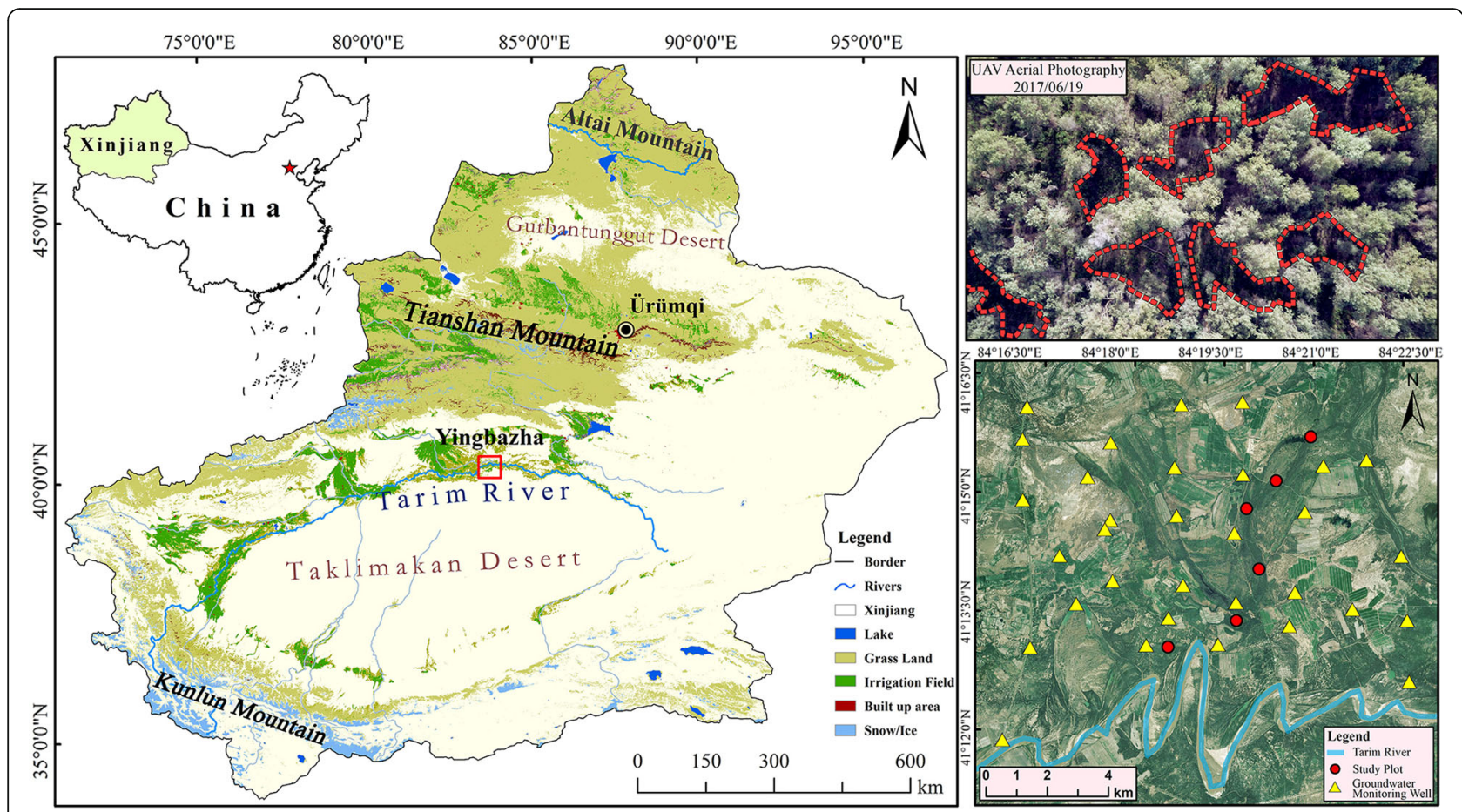

Fig. 1 Sketch map of the study area

Elaeagnus oxycarpa (Gries et al. 2003; Chen et al. 2004; Thevs 2006; Thevs et al. 2008; Huang et al. 2010; Lang et al. 2016; Halik et al. 2019).

\section{Field investigation}

A complete field survey was carried out from May 15 to June 20, 2017. A total of 60 canopy gaps were investigated in six replicate grid plots $(50 \mathrm{~m} \times 50 \mathrm{~m})$ (Table 1$)$.

Canopy gaps were created by tree mortality (i.e., death) or by $>50 \%$ loss of tree branches. The ratio of gap diameter to tree height on the border of the gap ( $R_{\mathrm{D} / \mathrm{H}}$ value) ranged from 0.4 to 2.2 (Keram et al. 2019), which is consistent with measurements reported by Zhu et al. (2015). For each canopy gap, all surrounding trees and gap makers were identified, and the species, diameter at breast height $(\mathrm{DBH})$, and tree height $(\mathrm{TH})$ or log length were recorded for each tree. Morphological characteristics were used to determine the degree of tree decomposition and the life expectancy of gap makers was estimated under the guidance of local experienced forest workers (Liu and Hytteborn 1991; Droessler and Von 2005; Thomas and Jurij 2006; Petritan et al. 2013; Wen 2016; Yang et al. 2017; Keram et al. 2019), and the relative ages of the gap makers were thus determined. In addition, we determined whether there were significant differences in the DBH distribution among living and dead trees. We regarded trees bordering canopy gaps as living trees and gap makers as dead trees. To investigate regeneration species, we selected five replicate plots in each habitat (CGAs, UCAs, and RBAs) and recorded the species and numbers of seedlings and saplings. We simultaneously compared the species diversity and density

Table 1 Characteristics of six natural stands sampled for analysis of tree mortality

\begin{tabular}{|c|c|c|c|c|c|c|c|c|c|c|c|}
\hline \multirow[t]{2}{*}{ Plots } & \multirow{2}{*}{$\begin{array}{l}\text { Area } \\
\left(\mathrm{m}^{2}\right)\end{array}$} & \multirow{2}{*}{$\begin{array}{l}\text { DRB } \\
(\mathrm{m})\end{array}$} & \multirow{2}{*}{$\begin{array}{l}\text { GWL } \\
\text { (m) }\end{array}$} & \multirow{2}{*}{$\begin{array}{l}\text { Lat. } \\
\text { (N) }\left(^{\circ}\right)\end{array}$} & \multirow{2}{*}{$\begin{array}{l}\text { Long. } \\
\text { (E) }\left(^{\circ}\right)\end{array}$} & \multirow{2}{*}{$\begin{array}{l}\text { Altitude } \\
\text { (m) }\end{array}$} & \multicolumn{2}{|l|}{ P. euphratica } & \multicolumn{2}{|l|}{ T. ramosissima } & \multirow{2}{*}{$\begin{array}{l}\text { Gap } \\
\text { openness } \\
\text { (\%) }\end{array}$} \\
\hline & & & & & & & Ave. DBH (cm) & Ave. TH (m) & Ave. DBH (cm) & Ave. TH (m) & \\
\hline 1 & $50 \times 50$ & 100 & 2.00 & 41.175 & 84.240 & 929 & 35.4 & 9.8 & 1.6 & 3.2 & 43.10 \\
\hline 2 & $50 \times 50$ & 150 & 2.68 & 41.229 & 84.333 & 920 & 21.6 & 12.1 & 4.2 & 2.6 & 66.16 \\
\hline 3 & $50 \times 50$ & 300 & 3.41 & 41.176 & 84.241 & 920 & 15.5 & 9.1 & 2.3 & 1.6 & 50.54 \\
\hline 4 & $50 \times 50$ & 600 & 4.55 & 41.174 & 84.237 & 916 & 23.5 & 11.0 & 3.2 & 2.4 & 41.38 \\
\hline 5 & $50 \times 50$ & 1200 & 5.45 & 41.252 & 84.340 & 915 & 28.4 & 10.5 & 5.4 & 2.2 & 52.41 \\
\hline 6 & $50 \times 50$ & 2400 & 7.50 & 41.228 & 84.334 & 916 & 21.1 & 12.1 & 2.6 & 1.7 & 52.12 \\
\hline
\end{tabular}

DRB Distance from river bank, GWL Groundwater level, DBH Diameter at the breast height, $T H$ Tree height 
in these plots. We defined a CGA as an area where the canopy gap $>10 \mathrm{~m}^{2}$. For the UCA, we chose plots around the canopy gaps in the study area; RBA plots were located near the riverbank, which were covered with excessive water. For each habitat, 15 repeated sampling plots $(10 \mathrm{~m} \times 10 \mathrm{~m})$ were set, giving a total of 45 sampling plots. In each plot, we counted the number of species, for seedlings $(\leq 10 \mathrm{~cm}$ tall) and saplings $(10-100$ cm tall) (Walker 2000).

\section{Data processing}

\section{Classifying the DBH structure of gap makers}

Over the entire area of canopy gaps, gap makers were classified into five categories according to their DBH and $\mathrm{TH}$ (Xu et al. 2016): Class I comprised juvenile trees $(\mathrm{DBH}<5 \mathrm{~cm}, \mathrm{TH}<4 \mathrm{~m})$, Class II comprised young trees $(5 \mathrm{~cm}<\mathrm{DBH}<10 \mathrm{~cm}, \mathrm{TH} \geq 4 \mathrm{~m})$, Class III comprised young/middle-aged trees $(10 \mathrm{~cm}<\mathrm{DBH}<15 \mathrm{~cm})$, Class IV comprised middle-aged trees $(15 \mathrm{~cm}<\mathrm{DBH}<20 \mathrm{~cm})$, and Class V comprised old trees $(\mathrm{DBH}>20 \mathrm{~cm})$.

\section{Dynamic index of gap maker structure}

The dynamic structure of gap makers was quantitatively analyzed. The dynamic index of population structure $\left(V_{P_{i}}\right)$ can be represented by the change trend of gap makers in various structures. If $0<V_{P i} \leq 1$, the quantity of gap makers increased with the $V_{P i}$ value; If $-1<V_{P i} \leq$ 0 , the quantity of gap makers decreased with the $V_{P i}$ value. The dynamic index of gap maker individuals $\left(V_{n}\right)$ without external disturbance is described by the following equation:

$$
\mathrm{V}_{n}=\frac{S_{n}-S_{n+1}}{\left(S_{n}-S_{n+1}\right)_{\max }} \times 100 \%
$$

where $S_{n}$ is the number of individuals in $n$ DBH class, $S_{n+1}$ is the number of individuals in $n+1 \mathrm{DBH}$ class of gap makers, and (...) max $_{\text {ax }}$ is the maximum value in the column. Below is the formula used to calculate the dynamic index of gap maker structure $\left(V_{P i}\right)$ :

$$
V_{p i}=\frac{1}{\sum_{n-1}^{K-1} S_{n}} \times \sum_{n-1}^{K-1}\left(S_{n} \cdot V_{n}\right)
$$

where $S_{n}$ and $V_{n}$ are the same as in Eq. (1), $K$ is the quantity of gap makers in different age classes, and the range of $V_{P i}$ is consistent with $V_{n}$. We used the formula proposed by Chen (1998) to calculate the dynamic index value under completely random $\left(V_{p i}{ }^{\prime}\right)$ and non-random $\left(V_{p i}{ }^{\prime \prime}\right)$ disturbances.

\section{Statistical analysis}

We have calculated species diversity according to the Margalef richness index and Shannon Wiener index (Ma 1994; Ma and Liu 1994). A fitting optimization $t$-test method was used to statistically analyze the change trend of gap makers that died in different years and to evaluate the distribution patterns of the DBH values of gap makers. We used a chi-square goodness-of-fit test to reveal the DBH distribution of dead trees versus living trees. Further, we comparatively analyzed plant regeneration density between the different habitats (CGAs, UCAs, and RBAs) using the Margalef and ShannonWiener indices. Values of $P<0.05$ were considered to be statistically significant. The data were organized using Excel 2015 (Microsoft, Redmond, USA) and analyzed using OriginPro 2016 (OriginLab Corp2016).

\section{Results}

\section{Tree mortality}

Among the 245 gap makers identified, the mean DBH was $20.80 \pm 9.03 \mathrm{~cm}$ (range $10.10-49.50 \mathrm{~cm}$ ) and there were significant variations in different years. The chisquare goodness-of-fit test showed that the DBH structure of gap makers presented a common curve distribution (Fig. 2). The DBH distribution of gap makers approximated a Gaussian fit $\left(R^{2}=0.762,0.749,0.829\right.$, $0.896,0.918$, and 0.364 , respectively; $P<0.05$ ). However, large young gap makers $(\mathrm{DBH}<15 \mathrm{~cm})$ were more common in the study area, especially in the 2007-2016 (Gaussian fit, $R^{2}=0.364, P<0.05$ ). During the investigation, we found that some young trees were injured or crushed by old trees.

In this study, we found that stream water was significantly negatively correlated with tree mortality rates over the last three decades. Based on the above data analysis, there was an ascending trend in the dynamic index of gap maker's population structure during the periods of 1977-1986, 1987-1996, 1997-2006, and 2007-2016, while in 1957-1966 and 1967-1976 there was a descending trend (Table 2). Furthermore, there was a considerable negative interaction between the dynamic index value of gap maker population structure and annual runoff; the equation of the fitted model was $y=-0.0215 x+0.6146\left(R^{2}=0.912, P<0.01\right)$ without external disturbances $\left(V_{p i}\right)$, while the equation of the fitted model was $y=-0.0005 x+0.0146\left(R^{2}=0.8405\right.$, $P<0.01)$ under completely random disturbances $\left(V_{p i}{ }^{\prime}\right)$ and $y=0.0032 x+0.112 \quad\left(R^{2}=0.356, \quad P<0.01\right) \quad$ under non-random disturbances $\left(V_{p i}{ }^{\prime \prime}\right) . V_{p i}$ and $V_{p i}{ }^{\prime}$ decreased markedly with increase of stream runoff in the study area (Fig. 3). The $V_{p i}{ }^{\prime}$ value became positive and tended to increase when the river dropped to $25.86 \times 10^{8} \mathrm{~m}^{3}$.

Comparison of the DBH distribution of dead trees and living trees showed significant variation with a high proportion of young dead trees (Fig. 4). As mentioned above, the trees surrounding CGAs and gap makers represented living trees and dead trees, respectively. Grid chart analysis showed that the median DBH of dead 

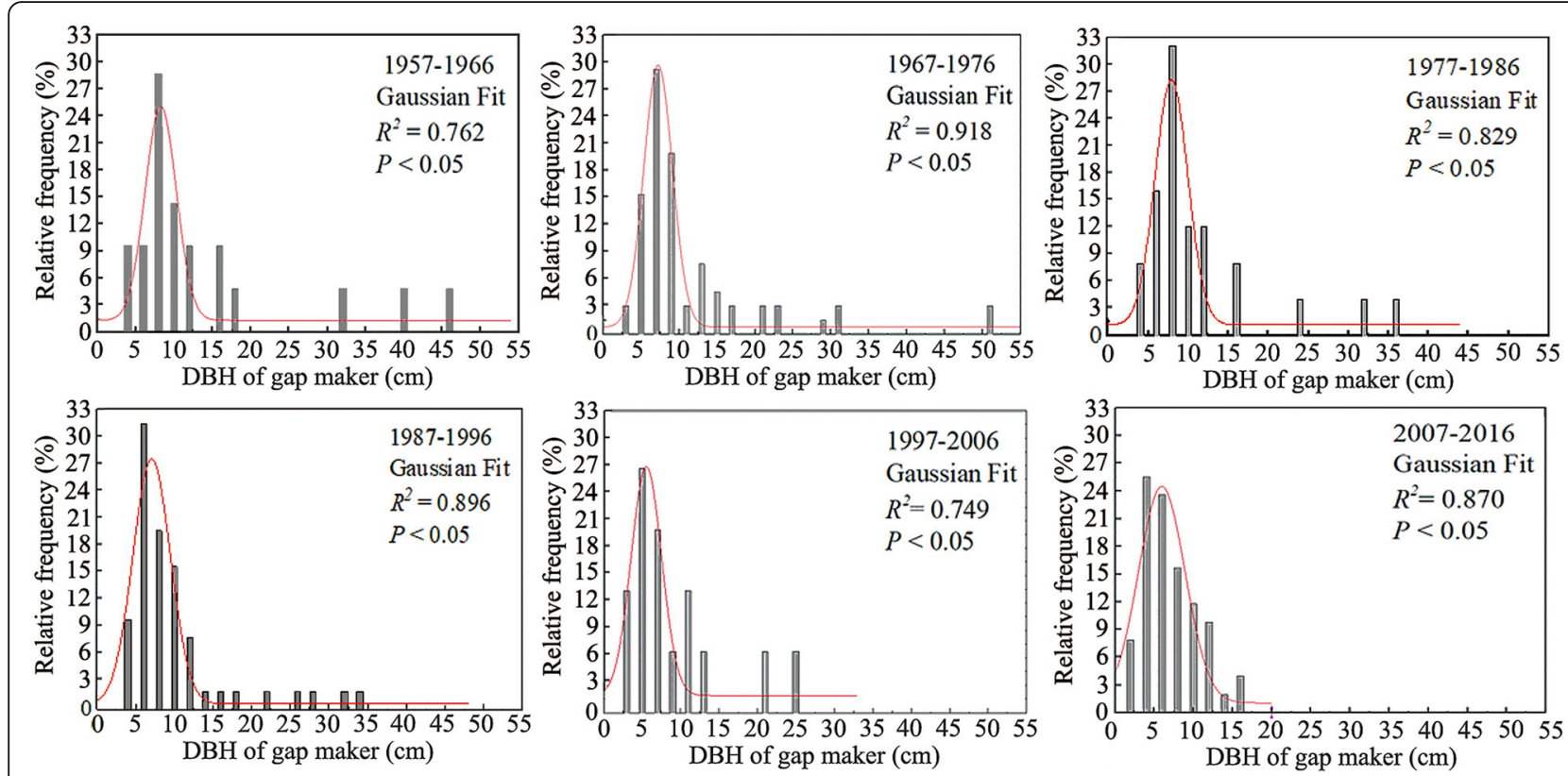

Fig. 2 Diameter class distribution of $P$. euphratica gap makers in the study area

trees, especially those died before 1996, were larger than that of living trees. However, by comparing DBH, we found that the trees that died in the 1997-2016 were smaller than living trees.

\section{Forest regeneration}

Riparian vegetation was distributed on both sides of the riverbank and was relatively simple and sparse in structure. In our field investigation, we counted 23 seedling and sapling species belonging to 12 families and 20 genera. In general, there were obvious differences in seedling and sapling regeneration among the habitats (CGAs, UCAs, and RBAs) (Table 3). Among the 14 plant species found in the CGAs, 7 were also found in the UCAs and 19 were also found in the RBAs; P. euphratica, T. ramosissima, T. hispida, T. leptostachys, G. uralensis and E. oxycarpa commonly appeared in all three habitats. P. pruinosa, P. hendersonii, C. segetum, C. auriculatum, A. pungens, T. mongolicum, M. platyphylla and $L$. ruthenicum were rare species, which only appeared in the RBAs. $P$. australis, $H$. halodendron and A. sparsifolia grew in the CGAs, but not in the UCAs or RBAs. Additionally, the RBAs contained a high number of $P$. euphratica species (30) compared to other habitats, and the number of $P$. euphratica and other species in the CGAs was higher than in the UCAs.

The seedling and sapling density of $P$. euphratica was significantly higher in the RBAs than in the CGAs and UCAs. However, compared with the UCAs, the CGAs promote tree regeneration to some extent by providing favorable conditions for the survival and growth of seedling and saplings (Table 4). We also performed quantitative analysis of seedling and sapling regeneration, based on species diversity and richness (Fig. 5). According to

Table 2 Analysis of population structure dynamics of gap makers under different volumes of runoff water

\begin{tabular}{lllllllllll}
\hline Years & Runoff $\left(\mathbf{1 0}^{\mathbf{8}} \mathbf{m}^{\mathbf{3}}\right)$ & $\boldsymbol{V}_{\mathbf{1}}$ & $\boldsymbol{V}_{\mathbf{2}}$ & $\boldsymbol{V}_{\mathbf{3}}$ & $\boldsymbol{V}_{\mathbf{4}}$ & $\boldsymbol{V}_{\boldsymbol{p} \boldsymbol{}}$ & $\boldsymbol{P}$ & $\boldsymbol{V}_{\boldsymbol{p}} \boldsymbol{i}^{\prime}$ & $\boldsymbol{P}^{\prime}$ & $\boldsymbol{V}_{\boldsymbol{p}}{ }^{\prime}$ \\
\hline $1957-1966$ & 33.34 & -0.92 & 0.75 & 0.69 & -0.67 & -0.073 & 0.0095 & -0.0040 & 0.2670 & -0.0180 \\
$1967-1976$ & 31.05 & -0.77 & 0.55 & 0.25 & 0.00 & -0.060 & 0.0040 & -0.0019 & 0.1430 & -0.0300 \\
$1977-1986$ & 27.85 & -0.84 & 0.78 & 0.71 & -0.60 & 0.000 & 0.0080 & 0.0025 & 0.5000 & 0.0600 \\
$1987-1996$ & 21.83 & 0.87 & 0.80 & 0.33 & -0.33 & 0.040 & 0.0039 & 0.0071 & 0.6350 & 0.0970 \\
$1997-2006$ & 22.84 & 0.00 & 0.40 & 1.00 & -1.00 & 0.200 & 0.0133 & 0.0057 & 0.5600 & 0.0400 \\
$2007-2016$ & 8.10 & -0.57 & 0.57 & 0.13 & 0.33 & 0.460 & 0.0154 & 0.0084 & 0.6599 & 0.0554 \\
\hline
\end{tabular}

$V_{1}$ I-II dynamic index value of I-II class sizes, $V_{2}$ II-III dynamic index value of II-III class sizes, $V_{3}$ III-IV dynamic index value of III-IV class sizes, $V_{4}$ IV-V dynamic index value of IV-V class sizes, $V_{p i}$ dynamic index value under no external disturbance, $V_{p i}{ }^{\prime}$ dynamic index value under completely random disturbance, $V_{p i}{ }^{\prime \prime}$ dynamic index value of non-random disturbance, $P$ maximum risk value under completely random disturbance, $P^{\prime}$ maximum risk value under non-random disturbance 


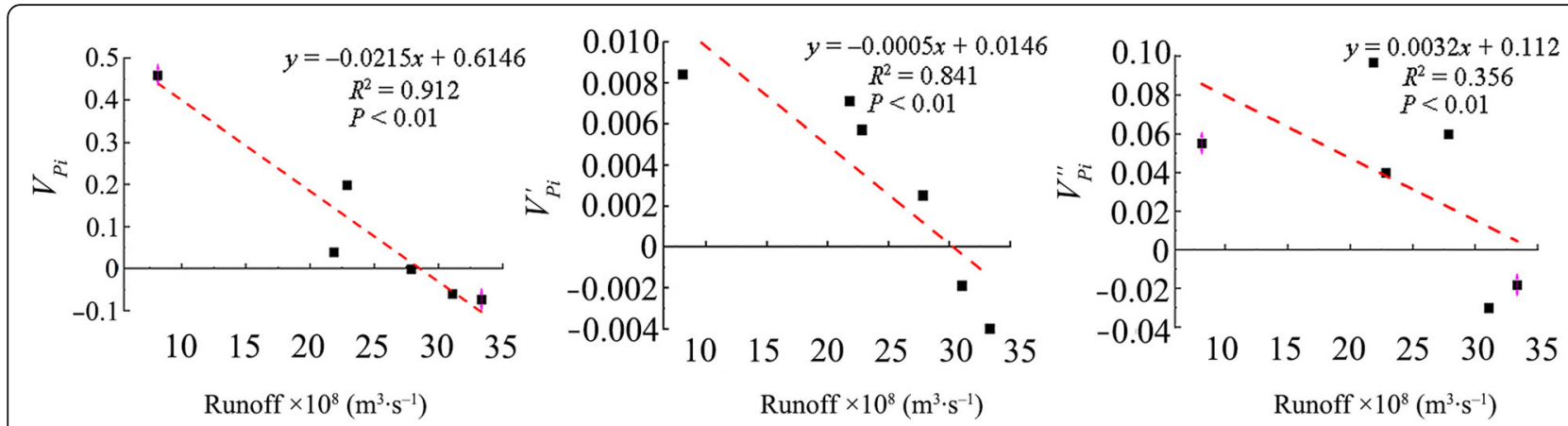

Fig. 3 Relationship between population structure dynamics of gap makers and annual runoff

analysis of the Margalef and Shannon-Wiener indices, the species diversity of seedlings and saplings was remarkably higher in the RBAs than in the other two areas, and higher in the CGAs than in the UCAs $(P<0.05)$. Further, though the density and diversity of seedlings and saplings in the CGAs was not as high as in the RBAs, the survival rate of young trees was higher in the CGAs than in the RBAs (Table 4).

\section{Comparison of gap makers and gap fillers}

The statistical analysis showed that P. euphratica is the most common species of gap maker. However, it also existed as gap filler, along with $T$. ramosissima and $P$. australis (Fig. 6). Other gap fillers included P. pruinosa, $A$. venetum, $H$. halodendron, $P$. hendersonii, $C$. segetum, C. auriculatum, A. pungens, T. mongolicum, S. collina,
C. pseudophragmites, M. platyphylla, H. glomeratu and E. oxycarpa, as well as some herbs such as G. glabra, I. salsoloides, K. caspica, L. ruthenicum, and A. sparsifolia, although they were very rare.

\section{Discussion}

One or more gap makers, i.e., dead trees, create canopy gaps in forests (Zang et al.1999). Keram et al. (2019) found that the mortality of gap makers did not substantially contribute to increased gap size in floodplain forests along the Tarim River. This could be explained by the small crown and DBH of gap makers. Tree mortality is caused by different agents, including drought or flooding, strong wind, diseases, and insect pests, and affects forest dynamics (Krasny and Whitmore 1992; Battles and Fahey 2000). Host-specific disturbance was
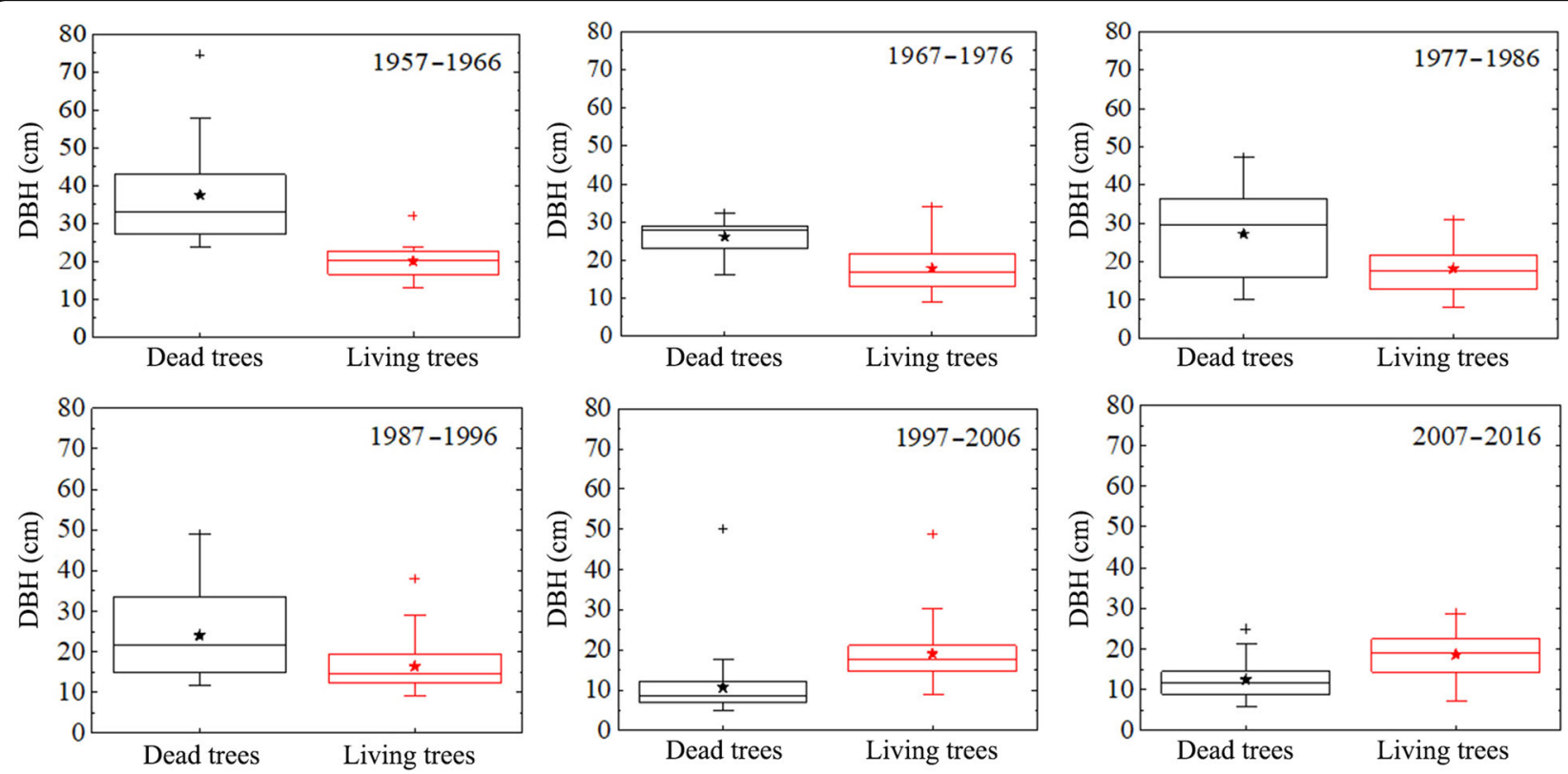

Fig. 4 Boxplots of the DBH of dead trees and living trees on the grid charts in canopy gaps that were created at different times. The box encloses the middle $80 \%$ of observations. Median and mean values are indicated by a vertical line (-) and a star ( $\star$ ), respectively. The upper whisker indicates the largest DBH value, while the lower whisker shows the smallest. The plus sign (+) indicates the maximum DBH 
Table 3 Seedling and sapling recruitment in different habitats in the study area

\begin{tabular}{|c|c|c|c|}
\hline Species & CGAs & UCAs & RBAs \\
\hline P. euphratica & 6 & 3 & 30 \\
\hline P. pruinosa & - & - & 5 \\
\hline T. ramosissima & 10 & 5 & 11 \\
\hline T. hispida & 3 & 2 & 4 \\
\hline T. leptostachya & 2 & 1 & 3 \\
\hline P. australis & 10 & - & - \\
\hline H. halodendron & 2 & - & - \\
\hline G. uralensis & 5 & 2 & 4 \\
\hline A. sparsifolia & 2 & - & - \\
\hline H. glomeratus & - & - & 2 \\
\hline K. caspica & 3 & - & 4 \\
\hline I. salsoloides & 1 & - & 2 \\
\hline P. hendersonii & - & - & 1 \\
\hline C. segetum & - & - & 2 \\
\hline C. auriculatum & - & - & 3 \\
\hline A. pungens & - & - & 2 \\
\hline S. collina & 2 & - & 4 \\
\hline C. pseudophragmites & 4 & - & 5 \\
\hline T. mongolicum & - & - & 3 \\
\hline M. platyphylla & - & - & 4 \\
\hline L. ruthenicum & - & - & 2 \\
\hline E. oxycarpa & 1 & 1 & 3 \\
\hline A. venetum & - & 3 & - \\
\hline
\end{tabular}

CGAs Canopy gap areas, UCAs Undercanopygap areas, RBAs Riverbank areas

considered to be the most common agent of tree mortality in old-growth mixed beech forests in the Western Carpathians (Orman and Dorota 2017), while wind disturbance led to a disproportionate number of gap makers in old-growth red spruce-Fraser fir forests in North Carolina (White et al. 1985) and red spruce-balsam stands in New Hampshire (Foster and Reiners 1986; Worrall et al. 2005). However, the causes of tree mortality in riparian forests are different from those in other forest types, such as tropical and subtropical forests. The results of the present study showed that tree mortality in riparian forests along the Tarim River was mainly influenced by hydrological factors (surface water), although strong winds or insect pests may also play a role (Han et al. 2011).

Water is the most important limiting factor for the maintenance and growth of $P$. euphratica in arid ecosystems, and $P$. euphratica depends on ground water that available to its roots (Yu et al. 2019). It is known that water is the factor with most influence on the survival, distribution, and development of vegetation in hyperarid regions. In arid ecosystems, the vitality of $P$. euphratica forests strongly depend on the groundwater level (Halik et al. 2006, 2009; Wang et al. 2008; Ginau et al. 2013; Keyimu et al. 2017). Halik et al. (2019) reported that the vitality of $P$. euphratica diminished when the groundwater level was not sufficient for the development of tree stands. In addition, Xu et al. (2016) studied the correlation between groundwater and surface water using stable isotope technology. Their results indicated that the groundwater level is significantly affected by surface water. Chen et al. (2004) and Keilholz et al. (2015) also demonstrated that groundwater is often supplied by stream flow and infiltration from watercourses. The groundwater depth in the Tarim Basin has dropped continuously as a result of the desiccation of streams and decreases in stream flow since an embankment was built in 2000. Thus, the physical characteristics of plant habitats have been changed. Consequently, the growth of $P$. euphratica cannot be sustained as before in this region, and forests have highly degraded or died. According to the present study, hydrological alterations may be the main cause of tree death in desert riparian forests along the Tarim River. DBH is one of the most common forest inventory variables and can reflect the population structure and growth status of tree stands (Condit et al. 2000; Di et al. 2014). Due to the unique climate and habitat conditions of desert floodplain areas, tree shape variables are obviously different from those in temperate or/and subtropical forests (Ling et al. 2015). In the present research, it was found that most young gap makers $(\mathrm{DBH}<15 \mathrm{~cm})$ died in the most recent two decades, i.e., 1997-2006 and 2007-2016. In the early 1970 s, water resources were affected on a regional scale by climate change and anthropogenic activities (increased water use for irrigation), and then lag effects led to a progressive decrease in surface water from 1984 and caused a reduction in groundwater from 2004 (Keram et al. 2019). This resulted in habitat deterioration and a

Table 4 Comparison of $P$. euphratica seedlings and saplings in different habitats in the middle reaches of the Tarim River

\begin{tabular}{|c|c|c|c|c|c|}
\hline Plot & $\begin{array}{l}\text { Occurrence } \\
\text { frequency (\%) }\end{array}$ & $\begin{array}{l}\text { Seedling and sapling } \\
\left.\text { density (Plant } \cdot \mathrm{m}^{-2}\right)\end{array}$ & Plant height (cm) & $\begin{array}{l}\text { Young tree density } \\
\left(\text { Plant } \cdot \mathrm{m}^{-2}\right)\end{array}$ & Plant height $(\mathrm{cm})$ \\
\hline CGAs & 45.63 & $0.12 \pm 0.06 b$ & $3.53 \pm 0.86 b$ & $8.31 \pm 1.64 a$ & $285.0 \pm 1.62 a$ \\
\hline UCAs & 34.52 & $0.08 \pm 0.03 b$ & $3.12 \pm 0.45 b$ & $0.28 \pm 0.06 b$ & $167.0 \pm 1.55 b$ \\
\hline RBAs & 100.00 & $17.56 \pm 3.12 \mathrm{a}$ & $18.76 \pm 3.95 a$ & $0.34 \pm 0.04 b$ & $187.0 \pm 1.51 b$ \\
\hline
\end{tabular}

CGAs canopy gap areas, UCAs undercanopy areas, RBAs riverbank areas 


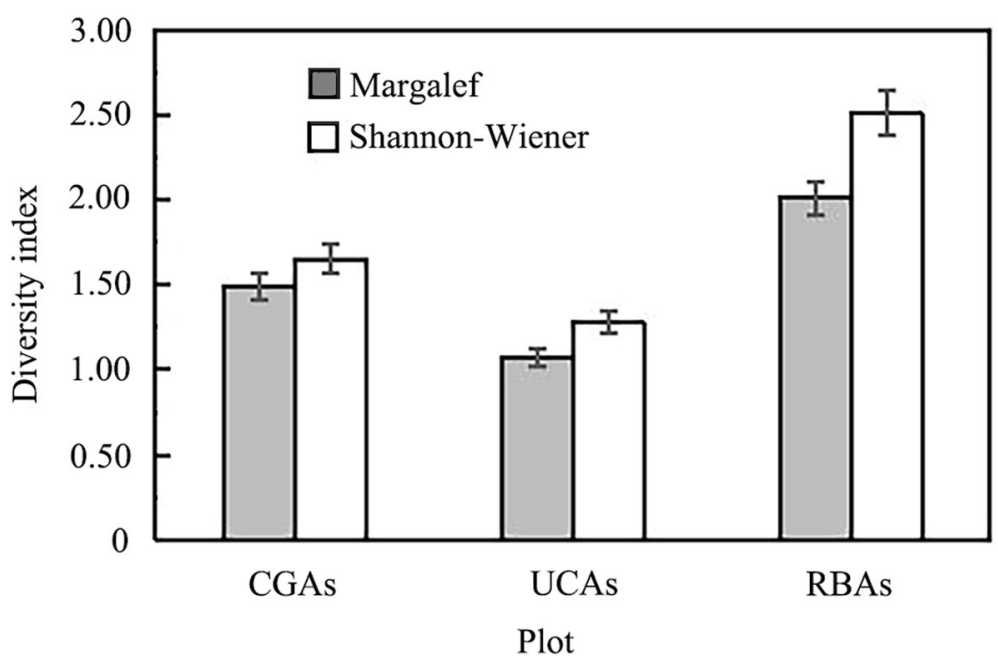

Fig. 5 Species diversity of seedlings and saplings in different habitats

decline in the survival of young $P$. euphratica individuals. Based on quantitative correlation analysis, the present study revealed that gap maker mortality and DBH structure responded negatively to variations in surface water. This may be due to long-lasting exogenous disturbances, such as a scarcity of surface water or a decrease in groundwater level, having a notable influence on vegetation through drought stress. Thus, the water requirement of riparian vegetation was not satisfied. Therefore, gap makers of low DBH appeared frequently in $P$. euphratica forests, which experienced an increase in more resilient species. This may be because the vitality of $P$. euphratica in this arid area was directly affected by the hydrological conditions, and only a small proportion of young trees survived to reach canopy height. However, there were a large number of larger, mature trees among the living trees that have developed root systems and are therefore not significantly affected by the reduced groundwater level.

By creating environmental heterogeneity in terms of light availability, gap disturbances play a key role in forest regeneration as well as in the establishment and development of tree species with different ecological recruitment patterns (Runkle 1989; Peterken 1996; Mountford 2006; Zhang et al. 2006; Li et al. 2013). Gapbased restoration provides a flexible system that

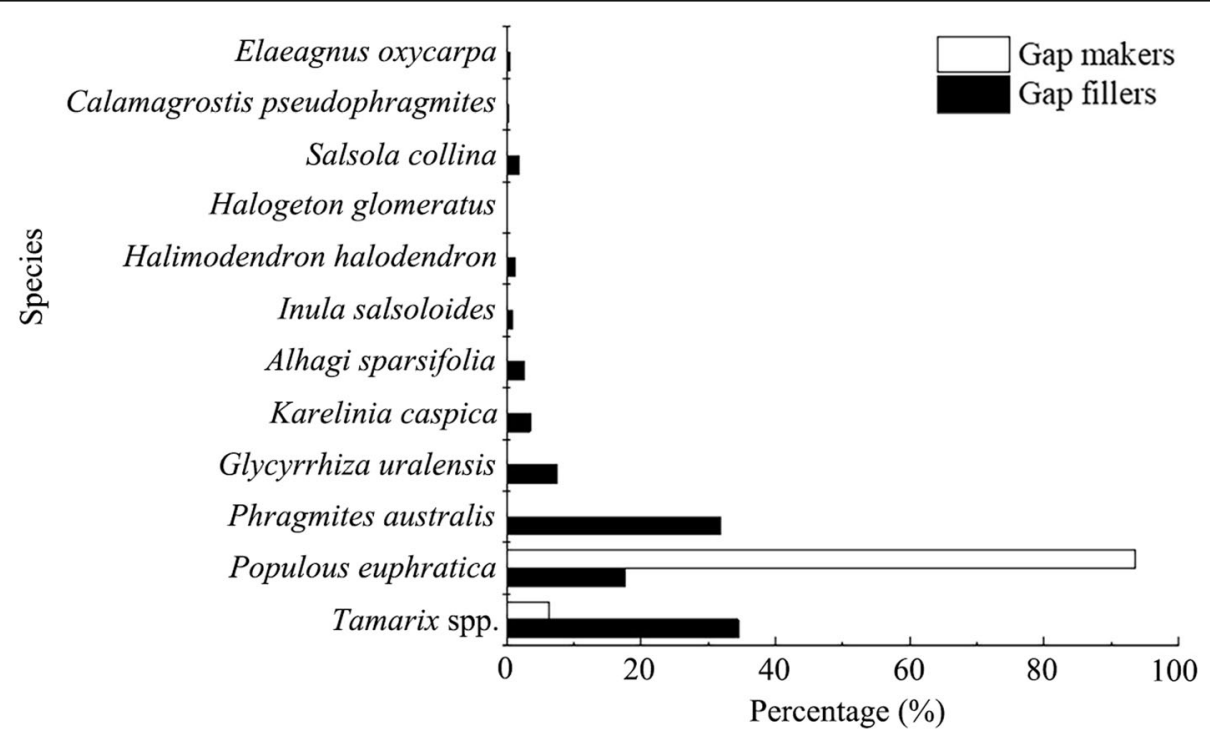

Fig. 6 Comparison of gap maker and gap filler species in the middle reaches of the Tarim River 
emulates natural regeneration under different environments. Van and Dignan (2007) reported that seedling and sapling diversity and richness were promoted by light intensity. Zhu et al. (2014) stated in a review of published studies that compared to UCAs, the seedlings and saplings of shade-tolerant species have significantly higher density in CGAs. Overall, water, light availability, and seedbed conditions potentially affect seedling emergence, germination, and establishment in floodplain riparian forests. It was found that appearance of seedling is closely related to flooding patterns in this study. Besides, a higher density of seedlings and saplings is expected in gaps as they provide full light conditions. The results of the present observations showed that the seedling and sapling species diversity was higher in the CGAs than in the UCAs. Hence, forest canopy gaps playing a pivotal role in the long-term germination and regeneration of plant species in some degree. Oliver and Larson (1996) stated that canopy gaps simultaneously result in mortality in some individuals and establishment and growth in others, and the ongoing process of death and replacement has a profound effect on forest structure and composition. Pham et al. (2004) showed that Abies balsamea is the most frequent successor in Abies forest stands and that Picea mariana is the most likely replacement species in Picea forest stands, regardless of the species of gap makers. In the present study, canopy gaps were filled with shrubs and herbs. When we examined the probability of replacement in floodplain forests, there seemed to be a reciprocal replacement of $P$. euphratica by T. ramosissima. and $P$. australis (Fig. 6). However, the probability of $P$. euphratica replacement was lower when the mortality of young trees was particularly high.

\section{Conclusion and suggestion}

As the largest riparian forest ecosystem in Northwest China, Euphrates poplar forests are facing great challenges of climate change and human interference (Zhang et al. 2016; Halik et al. 2019). Monitoring of tree mortality and plant regeneration in different habitats is considered the most effective way of ensuring the sustainable regeneration and ecological restoration of floodplain forests along the Tarim River. Based on evaluation of the correlation between tree mortality and water resources in the study area, hydrological conditions (runoff volume) are the main reason for the death of $P$. euphratica forests. At the beginning of the 1970s, hydrological conditions were affected on a regional scale by anthropogenic activities. Consequently, riparian forests were threatened under water scarcity, which resulted in high mortality among Populus species. Our observations of seedling and sapling density indicated that the frequency of plant species was different among the three studied habitats; it was highest in the RBAs, intermediate in the
CGAs, and lowest in the UCAs. It may have been affected by light availability and hydrological conditions during seedling and sapling recruitment.

In conclusion, searching the tree mortality and plant regeneration are considered to be the most effective ways to clarify the development trend of desert riparian forest. Furthermore, the protection and maintenance of the floodplain vegetation along the Tarim River are crucial to sustainable regional development in the Tarim Basin. Our study area is located in the Yingbazha section, where there are fragment pits of stagnant water by flooding. Moreover, though the density and diversity of seedlings and saplings in the CGAs was not as high as in the RBAs, the survival rate of young trees was higher in the CGAs than in the RBAs. Accordingly, we suggest that making full use of limited resources of stagnant water pits to establish a "Natural Nursery of the Poplar" and appropriately transplanted into the gap, the main purpose of which is to achieve an improved regeneration efficiency of the Populus euphratica riparian forests. Additionally, there is a need for further applied experiment to establish test areas for flood water allocation and utilization strategies, which, if successful, should then be extended to the whole basin. Thus, we argue that, to some degree, canopy gaps can provide a favorable environment for seedlings to grow into saplings, thereby reaffirming the importance of gap creation for forest regeneration.

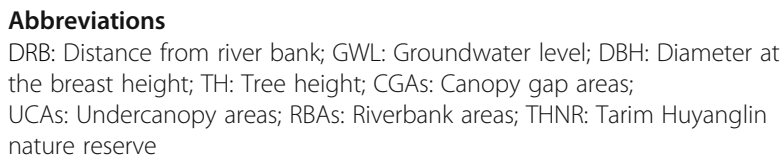

\section{Acknowledgments}

Cordial thanks to MSc-Students (Elyar, Wang Wenjuan, Ramile, Mihray and Gao Qing) from the Xinjiang University for their intensive support during the field investigation. Special thanks to Xinjiang LIDAR Applied Engineering Technology Research Center for giving us free use of the Riegl VZ-1000 Terrestrial Laser Scanner. We thank the anonymous reviewers for their constructive comments that greatly helped us improve the quality of this manuscript.

\section{Authors' contributions}

Ayjamal Keram conceived, designed and performed the experiments, contributed the data collection, analyzed the data, prepared figures and tables, and authored or approved the final draft of the manuscript. Ümüt Halik conceived and designed the experiments, contributed the data collection, reviewed the manuscript, and approved the final draft. Tayierjiang Aisahan, Maierdang Keyimu and Kadeliya Jiapaer participated in field work, contributed the data collection/validation and language proofreading. Guolei Li edited and validated the manuscript with critical comments and reviewed the manuscript draft. All authors checked and approved the final manuscript.

\section{Funding}

The work was funded by the National Natural Science Foundation of China (31860134, U1703102, 31700386).

Availability of data and materials

The data set generated for the study area is available from the corresponding author on reasonable request. 


\section{Declarations}

\section{Ethics approval and consent to participate}

Not applicable.

\section{Consent for publication}

Not applicable.

\section{Competing interests}

The authors declare that they have no competing interests.

\section{Author details}

${ }^{1}$ College of Resources and Environmental Science, Key Laboratory for Oasis Ecology of Ministry of Education, Xinjiang University, Ürümqi 830046, China. ${ }^{2}$ College of Forestry, Key Laboratory for Silviculture and Conservation of Ministry of Education, Beijing Forestry University, Beijing 100083, China. ${ }^{3}$ State Key Laboratory of Urban and Regional Ecology, Research Center for Eco-Environmental Sciences, Chinese Academy of Sciences, Beijing 100085 , China.

Received: 26 February 2021 Accepted: 9 June 2021

Published online: 22 July 2021

\section{References}

Aishan T (2016) Degraded Tugai forests under rehabilitation in the Tarim riparian ecosystem, Northwest China: monitoring, assessing and modeling. KU Eichstätt-Ingolstadt, Germany

Aishan T, Betz F, Halik Ü, Cyffka B, Rouzi A (2018) Biomass carbon sequestration potential by riparian forest in the Tarim River watershed, Northwest China: implication for the mitigation of climate change impact. Forests 9(4):196211. https://doi.org/10.3390/f9040196

Albanesi E, Gugliotta Ol, Mercurio L, Mercurio R (2005) Effects of gap size and within-gap position on seedlings establishment in silver fir stands. iForest 1(1):55-59. https://doi.org/10.3832/ifor0448-0010055

Battles JJ, Fahey TJ (2000) Gap dynamics following forest decline: a case study of red spruce forests. Ecol Appl 10(3):760-774. https://doi.org/10.2307/2641043

Betz F, Halik Ü, Kuba M, Aishan T, Cyffka B (2015) Controls on aeolian sediment dynamics by natural riparian vegetation in the eastern Tarim Basin, Northwest China. Aeolian Res 18:23-34. https:/doi.org/10.1016/j.aeolia.2015.04.005

Bottero A, Garbarino M, Dukić V, Govedar Z, Lingua E, Nagel TA (2011) Gap-phase dynamics in the old-growth forest of Lom, Bosnia and Herzegovina. Silv Fenn 45(5):875-887. https://doi.org/10.14214/sf.76

Chen XD (1998) A study on the method of quantitative analysis for plant population and community structural dynamics. Acta Ecol Sin 18(2):214-217

Chen YJ, Li WH, Liu JZ, Yang YH (2013) Effects of water conveyance embankments on riparian forest communities at the middle reaches of the Tarim River, Northwest China. Ecohydrology 6(6):937-948. https://doi.org/10.1 002/eco.1418

Chen YN, Wang Q, Ruan X, Li WH, Chen YP (2004) Physiological response of Populus euphratica to artificial water-recharge of the lower reaches of the Tarim River. Acta Bot Sin 46(12):1393-1401

China Green Foundation (2018) Ecological Restoration Plan of Populus euphratica Forest Along the Belt and Road. China Forestry Publishing House, Beijing

Coates KD, Philip JB (1997) A gap-based approach for development of silvicultural systems to address ecosystem management objectives. Forest Ecol Manag 99(3):337-354. https://doi.org/10.1016/S0378-1127(97)00113-8

Condit R, Ashton PS, Baker P, Bunyavejchewin S (2000) Spatial patterns in the distribution of tropical tree species. Science 288(5470):1414-1418. https://doi. org/10.1126/science.288.5470.1414

Deng MJ (2009) Theory and practice of water management in the Tarim River, China. Science Press, Beijing

Deng MJ (2016) Prospecting development of southern Xinjiang: water strategy and problem of Tarim River basin. Arid Land Geog 39(1):1-11

Di K, Guo YX, Ren CJ, Zhao FZ, Feng YZ, Han XH, Yang GH (2014) Population structure and spatial pattern of main tree species in secondary Betula platyphylla forest in Ziwuling Mountains, China. Sci Rep 4(1):6873. https://doi. org/10.1038/srep06873

Dorotä D, Thomast V (2008) Tree fall-gap structure and regeneration in mixed Abies alba stands in Central Poland. Forest Ecol Manag 255(8):3469-3476. https://doi.org/10.1016/j.foreco.2008.02.025
Droessler L, Von LB (2005) Canopy gaps in two virgin beech forest reserves in Slovakia. J Sci 51(10):446-457. https://doi.org/10.17221/4578-JFS

Foetzki A (2004) Transpiration and sap flow in Alhagi sparsifolia, Calligonum caput-medusae, Populus euphratica and Tamarix ramosissima. In: Runge M, Zhang $X$ (eds) Ecophysiology and habitat requirements of perennial plant species in the Taklimakan Desert. Shaker Press, Aachen, pp 67-74

Foster JR, Reiners WA (1986) Size distribution and expansion of canopy gaps in a northern Appalachian spruce-fir forest. Vegetatio 68(2):109-114

Ginau A, Opp C, Sun Z, Halik Ü (2013) Influence of sediment, soil, and micro-relief conditions on vitality of Populus euphratica stands in the lower Tarim riparian ecosystem. Quatern Intern 311:146-154. https://doi.org/10.1016/j.quaint.2013. 06.025

Gries D, Zeng F, Foetzki A, Arndt SK, Bruelheide H, Thomas FM (2003) Growth and water relations of Tamarix ramosissima and Populus euphratica on Taklamakan desert dunes in relation to depth to a permanent water table. Plant Cell Environ 26(5):725-736. https://doi.org/1 0.1046/j.1365-3040.2003.01009x

Halik Ü, Aishan T, Betz F, Kurban A, Rouzi A (2019) Effectiveness and challenges of ecological engineering for desert riparian forest restoration along China's largest inland river. Ecol Eng 127:11-22. https://doi.org/10.1016/j.ecoleng.201 8.11 .004

Halik Ü, Chai Z, Kurban A, Cyffka B (2009) The positive response of some ecological indices of Populus euphratica to the emergency water transfer in the lower reaches of the Tarim River. Res Sci 31:1309-1314. https://doi.org/1 $0.1007 / 978-3-642-00205-2$ - 9

Halik Ü, Kurban A, Mijit M, Schulz J, Parroth F, Coenradie B (2006) The potential influence of embankment engineering and ecological water transfer on the riparian vegetation along the middle and lower reaches of the Tarim River. In: Hoppe T, Kleinschmit B, Roberts B, Thevs N, Halik Ü (eds) Watershed and floodplain management along the Tarim River in China's arid northwest. Shaker Press, Aachen, pp 221-236

Han L, Wang H, Chen J (2011) Disturbance regimes and gaps characteristics of the desert riparian forest at the middle reach of Tarim River. Acta Ecol Sin 31(16):4699-4708. https://doi.org/10.1007/s11676-011-0113-8

Han WJ, He JF, Zhang WH, Li JX (2013) Effects of gap size on root growth of seedlings and soil physical and chemical properties in plantation in the Huanglong forest. Sci Silv Sin 11(49):17-23

Hu S, Zhao R, Tian C, Song Y (2009) Empirical models of calculating phreatic evaporation from bare soil in Tarim River basin, Xinjiang. Environ Geol 59(3): 663-668. https://doi.org/10.1007/s12665-009-0063-z

Huang P (2002) Irrigation-free vegetation and its recovery in arid region. Science Press, Beijing, pp 15-50

Huang T, Pang Z (2011) Changes in groundwater induced by water diversion in the lower Tarim River, Xinjiang Uygur, NW China: evidence from environmental isotopes and water chemistry. J Hydrol 387(3-4):188-201. https://doi.org/10.1016/j.jhydrol.2010.04.007

Huang X, Chen YN, Ma JX, Chen YP (2010) Study on change in value of ecosystem service function of Tarim River. Acta Ecol Sin 30(2):67-75. https:// doi.org/10.1016/i.chnaes.2010.03.004

Jankovska I, Brūmelis G, Nikodemus O, Kasparinskis R, Amatniece V, Straupmanis $G$ (2015) Tree species establishment in urban forest in relation to vegetation composition, tree canopy gap area and soil factors. Forests 6(12):4451-4461. https://doi.org/10.3390/f6124379

Keilholz P, Disse M, Halik Ü (2015) Effects of land use and climate change on groundwater and ecosystems at the middle reaches of the Tarim River using the MIKE SHE integrated hydrological model. Water 7(12):3040-3056. https:// doi.org/10.3390/w7063040

Keram A, Halik Ü, Keyimu M, Aishan T, Mamat Z, Rouzi A (2019) Gap dynamics of natural Populus euphratica floodplain forests affected by hydrological alteration along the Tarim River: implications for restoration of the riparian forests. Forest Ecol Manag 438:103-113. https://doi.org/10.1016/j.foreco.2019.02.009

Kern CC, Burton J, Raymond P. D'Amato AW, Keeton WS (2017) Challenges facing gap-based silviculture and possible solutions for Mesic northern forests in North America. Forestry 90(1):4-17. https://doi.org/10.1093/forestry/ cpw024

Kern CC, Montgomery RA, Reich PB, Strong TF (2013) Canopy gap size influences niche partitioning of the ground-layer plant community in a northern temperate forest. J Plant Ecol 6(1):101-112. https://doi.org/10.1093/jpe/rts016

Keyimu M, Halik Ü, Rouzi A (2017) Relating water use to tree vitality of Populus euphratica Oliv. In the lower Tarim River, NW China. Water 8(9):622. https:// doi.org/10.3390/w9080622 
Keyimu M, Halik Ü, Wumaier G, Abliz A (2018) Diel variation of Populus euphratica sap flow and its correlation with meteorological factors. J Glaciol Geocryol 40(1):166-175

Kitao M, Kitaoka S, Harayama H (2018) Canopy nitrogen distribution is optimized to prevent photo inhibition throughout the canopy during sun flecks. Sci Rep 8(1):503-513. https://doi.org/10.1038/s41598-017-18766-0

Krasny ME, Whitmore MC (1992) Gradual and sudden forest canopy gaps in Allegheny northern hardwood forests. Can J Forest Res 22(2):139-142. https://doi.org/10.1139/x92-019

Lang P, Ahlborn J, Schäfer P, Wommelsdorf T, Jeschke M, Zhang X, Thomas FM (2016) Growth and water use of Populus euphratica trees and stands with different water supply along the Tarim River, Northwest China. Forest Ecol Manag 380:139-148. https://doi.org/10.1016/j.foreco.2016.08.049

Li ZP, Li WM, Wu FZ, Yang WQ, Xu ZF, Tan P, Wu QG (2013) Effects of forest gap on content of soil nit rate nitrogen and ammonium nitrogen at different critical periods of subalpine forest in Western Sichuan. J Soil Water Conserv 6(27):270-274

Ling H, Zhang P, Xu H, Zhao X (2015) How to regenerate and protect desert riparian Populus euphratica forest in arid areas. Sci Rep 5(154):81-89. https:// doi.org/10.1038/srep15418

Liu Q, Hytteborn H (1991) Gap structure, disturbance and regeneration in a primeval Picea abies forest. J Veg Sci 2(3):391-402. https://doi.org/10.23 07/3235932

Lu DL, Wang GG, Yan QL, Gao T, Zhu JJ (2018) Effects of gap size and within-gap position on seedling growth and biomass allocation: is the gap partitioning hypothesis applicable to the temperate secondary forest ecosystems in Northeast China? Forest Ecol Manag 429:351-362. https://doi.org/10.1016/j. foreco.2018.07.031

Ma KP (1994) Measurement of biotic community diversity: I. a diversity (part. 1). Biodivers Sci 2(3):162-168. https://doi.org/10.17520/biods.1994027

Ma KP, Liu YM (1994) Measurement of biotic community diversity: I. a diversity (part. 2). Biodive Sci 2(4):231-239. https://doi.org/10.17520/ biods.1994027

Mamat Z, Halik Ü, Aishan T, Aini A (2019) Ecological effect of the riparian ecosystem in the lower reaches of the Tarim River in Northwest China. Plos One 14(1):e0208462. https://doi.org/10.1371/journal.pone.0208462

Mamat Z, Halik Ü, Keyimu M, Keram A, Nurmamat K (2018) Variation of the floodplain forest ecosystem service value in the lower reaches of the Tarim River, China. Land Degrad Dev 29(1):47-57. https://doi.org/10.1002/ldr.2835

Mountford EP (2006) Patterns of regeneration and ground vegetation associated with canopy gaps in a managed beechwood in southern England. Forestry 79(4):389-408. https://doi.org/10.1093/forestry/cpl024

Nagel TA, Svoboda M (2008) Gap disturbance regime in an old-growth Fagus abies forest in the Dinaric Mountains, Bosnia-Herzegovina. Can J For Res 38(11):2728-2737. https://doi.org/10.1139/X08-110

Nagel TA, Svoboda M, Kobal M (2016) Disturbance, life history traits, and dynamics in an old-growth forest landscape of southeastern Europe. Ecol Appl 24(4):663-679. https://doi.org/10.1890/13-0632.1

Nagel TA, Svoboda M, Rugani T, Diaci J (2010) Gap regeneration and replacement patterns in an old-growth Fagus-Abies forest of BosniaHerzegovina. Plant Ecol 208(2):307-318. https://doi.org/10.1007/s11258-0099707-z

Oliver CD, Larson BC (1996) Forest stand dynamics. Willey, New York

Orman O, Dorota D (2017) Gap dynamics in the Western Carpathian mixed beech old growth forests affected by spruce bark beetle outbreak. Eur J Forest Res 136(4):571-581. https://doi.org/10.1007/s10342-017-1054-3

Peterken GF (1996) Natural woodland: ecology and conservation in northern temperate regions (2001 reprint). J Ecol 84(5):790. https://doi.org/10.2307/22 61344

Petritan AM, Nuske RS, Petritan IC (2013) Gap disturbance patterns in an oldgrowth sessile oak (Quercus petraea L.), European beech (Fagus sylvatica L.) forest remnant in the Carpathian Mountains, Romania. Forest Ecol Manag 308(4):67-75. https://doi.org/10.1016/j.foreco.2013.07.045

Pham AT, Grandpré LD, Gauthier S, Bergeron Y (2004) Gap dynamics and replacement patterns in gaps of the northeastern boreal forest of Quebec. Can J For Res 34(2):353-364. https://doi.org/10.1139/x03-265

Popa I, Nechita C, Hofgaard A (2017) Stand structure, recruitment and growth dynamics in mixed subalpine spruce and Swiss stone pine forests in the eastern Carpathians. Sci Total Environ 598:1050-1057. https://doi.org/10.1016/ j.scitotenv.2017.04.169
Rentch JS, Schuler TM, Nowacki GJ, Beane NR, Ford WM (2010) Canopy gap dynamics of second-growth red spruce-northern hardwood stands in West Virginia. Forest Ecol Manag 260(10):1921-1929. https://doi.org/10.1016/j. foreco.2010.08.043

Rouzi A, Halik Ü, Thevs N, Aishan T (2018) Water efficient alternative crops for sustainable agriculture along the Tarim Basin: a comparison of the economic potentials of Apocynum pictum, Chinese red date and cotton in Xinjiang, China. Sustainability 10(1):1-17. https://doi.org/10.3390/su10010035

Rumbaur C, Thevs N, Disse M (2015) Sustainable management of river oases along the Tarim River (SuMaRiO) in northwestern China under conditions of climate change. Earth Sys Dynam 5(2):1221-1273. https://doi.org/10.5194/ esd-6-83-2015

Runkle JR (1989) Synchrony of regeneration, gaps, and latitudinal differences in tree species diversity. Ecology 70(3):546-547. https://doi.org/10.2307/1940199

Runkle JR (1998) Changes in southern Appalachian canopy tree gaps sampled thrice. Ecology 79(5):1768-1780. https://doi.org/10.2307/176795

Runkle JR, Yetter TC (1987) Treefalls revisited: gap dynamics in the southern Appalachians. Ecology 68(2):417-424. https://doi.org/10.2307/1939273

Schliemann SA, Bockheim JG (2011) Methods for studying tree fall gaps: a review. Forest Ecol Manag 261(7):1143-1151. https://doi.org/10.1016/j. foreco.2011.01.011

Sharma LN, Shrestha KB, Maren IE (2018) Tree regeneration in gap-understory mosaics in a subtropical shorea robusta (Sal) forest. J Forest Res 30(6):20612068. https://doi.org/10.1007/s11676-018-0747-x

Song YD, Fan ZL, Lei ZD, Zhang FW (2000) Research on water resources and ecology of Tarim River, China. Xinjiang People's Press, China, Beijing

Thevs N (2006) Ecology, spatial distribution, and utilization of the Tugai vegetation at the middle reaches of the Tarim River, Xinjiang, China. ErnstMoritz-Arndt University of Greifswald, Germany

Thevs N, Zerbe S, Schnittler M, Abdusalih N, Succow M (2008) Structure, reproduction and flood-induced dynamics of riparian Tugai forests at the Tarim River in Xinjiang, NW China. Forestry 81(1):45-57. https://doi.org/10.1 093/forestry/cpm043

Thomas AN, Jurij D (2006) Intermediate wind disturbance in an old-growth beech-fir forest in south eastern Slovenia. Can J For Res 36(3):629-638. https://doi.org/10.1139/x05-263

Thomas FM, Lang P (2020) Growth and water relations of riparian poplar forests under pressure in Central Asia's Tarim River basin. River Res Applic 37(2):233248. https://doi.org/10.1002/rra.3605

Thomas FM, Yu R, Schäfer P, Zhang XM, Petra L (2017) How diverse are Populus "diversifolia" leaves? Linking leaf morphology to eco-physiological and stand variables along water supply and salinity gradients. Flora 233:68-78. https:// doi.org/10.1016/j.flora.2017.05.007

Van PJD, Dignan P (2007) Regeneration after 8 years in artificial canopy gaps in mountain ash (Eucalyptus regnans) forest in south-eastern Australia. Forest Ecol Manag 244(1):102-111. https://doi.org/10.1016/j.foreco.2007.03.055

Walker LR (2000) Seedling and sapling dynamics of treefall pits in Puerto Rico1. Biotropica 32(2):262-275. https://doi.org/10.1111/j.1744-7429.2000.tb00469.x

Wang JS, Halik Ü, Cyffka B, Kurban O, Peng SH (2008) Study on DBH-structure of Populus euphratica and their spatial distribution in the lower reaches of the Tarim River. Chin Bull Bot 25(6):728-733. https://doi.org/10.3969/j.issn.1674-34 66.2008.06.014

Wang SJ, Chen BH, Li HQ (1995) Euphrates poplar forest, 1st end. China Environ Sci Press, Beijing

Wen K (2016) Study on the relationship among Abies faxoniana regeneration, canopy gaps, and Fargesia denudate in subalpine coniferous forest in southwestern Sichuan, China. Beijing Forestry University, Beijing

White PS, Mackenzie MD, Busing RT (1985) Natural disturbance and gap phase dynamics in southern Appalachian spruce-fir forests. Can J For Res 15(1):233240. https://doi.org/10.1139/×85-041

Worrall JJ, Lee TD, Harrington TC (2005) Forest dynamics and agents that initiate and expand canopy gaps in Picea-abies forests of Crawford notch, New Hampshire, USA. J Ecol 93(1):178-190. https://doi.org/10.1111/j.1365-2745.2 004.00937.x

Xu C, Chen Y, Li W (2006) Climate change and hydrologic process response in the Tarim River basin over the past 50 years. Chin Sci Bull 51(1):25-36. https://doi.org/10.1007/s11434-006-8204-1

Xu MC, Chen YJ, Liu JZ, Wang D, Liu YQ (2016) The distribution pattern dynamics of Populus euphratica are influenced by hydrology in the middle reaches of Tarim River. Acta Ecol Sin 36(9):2646-2655 
Yamamoto SI (2000) Forest gap dynamics and tree regeneration. J Forest Res 5(4):223-230. https://doi.org/10.1007/BF02767114

Yang H, Liu SR, Cao KF, Wang JX, Li YD, Xu H (2017) Characteristics of typhoon disturbed gaps in an old-growth tropical montane rainforest in Hainan Island, China. J Forest Res 28(6):1231-1239. https://doi.org/10.1007/s11676-01 7-0402-y

Yu HY, Ya NC, We HL (2009) Relationship between soil properties and plant diversity in a desert riparian forest in the lower reaches of the Tarim River, Xinjiang, China. Arid Soil Res Rehab 23(4):283-296. https://doi.org/10.1080/1 5324980903231991

Yu TF, Feng Q, Si JH, Xi HY, O'Grady AP, Pinkard EA (2019) Responses of riparian forests to flood irrigation in the hyper-arid zone of NW China. Sci Total Environ 648:1421-1430. https://doi.org/10.1016/j.scitotenv.2018.08.287

Zang RG, Liu JY, Dong DF (1999) Gap dynamics and forest biodiversity. China Forestry Publishing House, Beijing, pp 1-242

Zeng F, Zhang X, Foetzki A, LiX RM (2002) Study on the water physiological characteristics of Populus euphratica in the Cele oasis. Arid Zone Res 19(2): 26-30

Zeng FJ, Bleby TM, Landman PA (2006) Water and nutrient dynamics in surface roots and soils are not modified by short-term flooding of phreatophytic plants in a hyperarid desert? Plant Soil 279(1-2):129-139. https://doi.org/10.1 007/s11104-005-0498-2

Zeng FJ, Zhang WJ, Liu GJ, Zhang DY, Li XY, Zhang L, Yuan LM, Zhang XM (2020) Stable restoration pattern and sustainable management technology of main dominant vegetation in typical desert areas of China. Bull Chin Acad Sci 214(6):63-70

Zhang CY, Zhao XH, Zheng JM (2006) A study on soil properties in forest gaps and under canopy in broad-leaved Pinus koraiensis forest in Changbai Mountain. Forest Res 19(3):347-352

Zhang Q, Gu XH, Singh VP (2016) Magnitude, frequency and timing of floods in the Tarim River basin, China: changes, causes and implications. Glob Planet Chang 139:44-55. https://doi.org/10.1016/j.gloplacha.2015.10.005

Zhao ZY, Zhang K, Lu L (2011) Seedling recruitment in desert riparian forest following river flooding in the middle reaches of the Tarim River. Acta Ecol Sin 31(12):3322-3329. https://doi.org/10.3724/SP.J.1011.2011.00338

Zhu JJ, Lu DL, Zhang WD (2014) Effects of gaps on regeneration of woody plants: a meta-analysis. J Forest Res 25(3):501-510. https://doi.org/10.1007/ s11676-014-0489-3

Zhu JJ, Mao ZH, Hu LL, Zhang JX (2007) Plant diversity of secondary forests in response to anthropogenic disturbance levels in montane regions of northeastern China. J Forest Res 12(6):403-416. https://doi.org/10.1007/s1031 0-007-0033-9

Zhu JJ, Matsuzaki T, Li FQ (2003) Effect of gap size created by thinning on seedling emergency, survival and establishment in a coastal pine forest. Forest Ecol Manag 182(1-3):339-354. https://doi.org/10.1016/50378-1127(03 )00094-X

Zhu JJ, Yan Q, Yu LZ, Zhang J, Yang K, Gao T (2018) Support ecological restoration and sustainable management of forests in Northeast China based on research of forest ecology and demonstrations. Bull Chin Acad Sci 33(1): $107-118$

Zhu JJ, Zhang GQ, Wang GG (2015) On the size of forest gaps: can their lower and upper limits be objectively defined. Agric For Meteorol 213(2):64-76. https://doi.org/10.1016/j.agrformet.2015.06.015

Zhu JJ, Zhu CY, Lu DL, Wang GG, Zheng X, Cao JS, Zhang JX (2021) Regeneration and succession: a 50-year gap dynamic in temperate secondary forests, Northeast China. Forest Ecol Manag 484:118943. https://doi.org/10.1016/j. foreco.2021.118943

\section{Submit your manuscript to a SpringerOpen ${ }^{\circ}$ journal and benefit from:}

- Convenient online submission

- Rigorous peer review

- Open access: articles freely available online

- High visibility within the field

- Retaining the copyright to your article

Submit your next manuscript at $\boldsymbol{\nabla}$ springeropen.com 